Association of University Teachers (CAUT).

4. The word "teacher" as used in this document is understood to include the investigator who is attached to an academic institution without teaching duties.

5. Bold-face numbers in brackets refer to Interpretive Comments which follow.

6. For a discussion of this question, see the "Report of the Special Committee on Academic Personnel Ineligible for Tenure," AAUP Bulletin, Autumn, 1966, pp. 280-282.

7. For a more detailed statement on this question, see "On Crediting Prior Service Elsewhere as Part of the Probationary Period," AAUP Bulletin 64 (1978): 274-75.

8. The common Federal Policy for the Protection of Human Subjects is based on and replaces 1981 regulations of the Department of Health and Human Services. Those regulations were examined by the AAUP in 1981: "Regula- tions Governing Research on Human Subjects: Academic Freedom and the Institutional Review Board, Academe, December 1981: 358-370.

9. 1961 Statement on Recruitment and Resignation of Faculty Members

1964 Committee A Statement on Extramural Utterances (Clarification of sec. 1c of the 1940 Statement of Principles on Academic Freedom and Tenure)

1965 Preventing Conflicts of Interest in Government-Sponsored Research at Universities

1966 Statement on Government of Colleges and Universities 1967 Joint Statement on Rights and Freedoms of Students 1970 Council Statement on Freedom and Responsibility 1976 On Discrimination

1984 Sexual Harassment: Suggested Policy and Procedures for Handling Complaints

\title{
African Americans in the Political Science Profession*
}

\author{
Sheila Ards, University of Maryland, College Park \\ Maurice C. Woodard, Howard University and the American Political Science Association
}

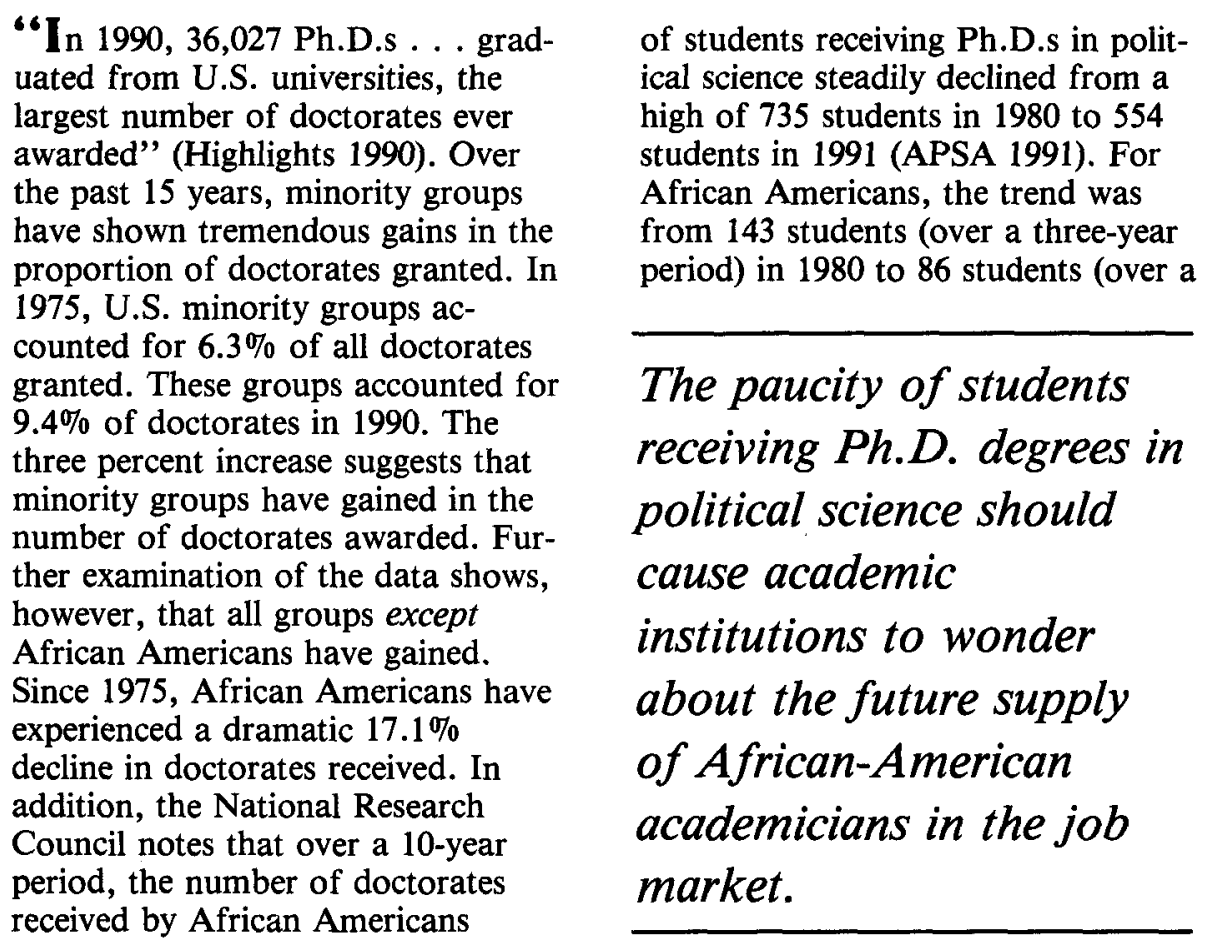

declined by an ostensible $23.2 \%$ (Chronicle of Higher Education 1990).

In the political science profession, the total number of Ph.D.s granted has declined over the past 11 years. Between 1980 and 1991, the number three-year period) in 1991. Even these numbers should be used with caution since some universities often include the names of all students of color, even those who are not U.S. citizens.

The paucity of students receiving
$\mathrm{Ph} . \mathrm{D}$. degrees in political science should cause academic institutions to wonder about the future supply of African-American academicians in the job market. There is a pressing need to look at how many students are in the pipeline-how many students are currently working on Ph.D. degrees. Unlike other student groups, the future supply of African Americans receiving Ph.D.s looks dismal. The already low number of the current supply of Ph.D.s and the dismal prospects for producing any new Ph.D.s justify a reassessment of the process that produces political science Ph.D.s from this minority group.

The purposes of this paper are two-fold:

1. to examine the process of production of new African-American Ph.D.s in political science, public administration, public affairs, and international relations; and

2. to analyze the incremental gains of African-American tenure-track professors in political science departments. 


\section{The Production of New African-American Ph.D.s}

A quasi-input-output analysis is used in this paper to examine the process of production of AfricanAmerican Ph.D.s. Basically, the number of students beginning Ph.D. programs in political science, the number of students presently in $\mathrm{Ph}$.D. programs, and the number of students receiving Ph.D. degrees are examined. Data obtained by the American Political Science Association (APSA) over a ten-year period enable an examination of trends in each of these categories. In addition, the top producers of African-American Ph.D.s in political science are listed. The production of AfricanAmerican PhD.s granted in subfields of the political science discipline by nontraditional political science departments or separate schools in the discipline are also examined.

\section{Trends of African Americans in Ph.D. Programs}

Figure 1 presents a graphical picture of African Americans in Ph.D. programs in political science between 1980 and 1991. The number of African Americans in Ph.D. programs around the country declined from 424 students in 1980 to 300 students in 1991. Although there were peaks in 1986 and 1990 after years of decline, these peaks did not reach the 1980 level. The lowest level of African Americans in Ph.D. programs was in 1988 when it reached a level of 256 students, followed by the 1987 level of 267 students.

Several explanations may be posited for the decline in the numbers of African-American students in Ph.D. programs. One explanation is the decline in the number of students of this group entering these programs. In 1980, 107 African-American students began pursuing doctoral study. In 1991, that number was only 71 . The year with the smallest number of African-American students beginning Ph.D. programs was in 1987. In that year, only 46 of these students entered Ph.D. programs around the country, and some of these may have been non-U.S. citizens.

Another hypothesis of why one may see a decline in the number of

FIGURE 1.

African Americans

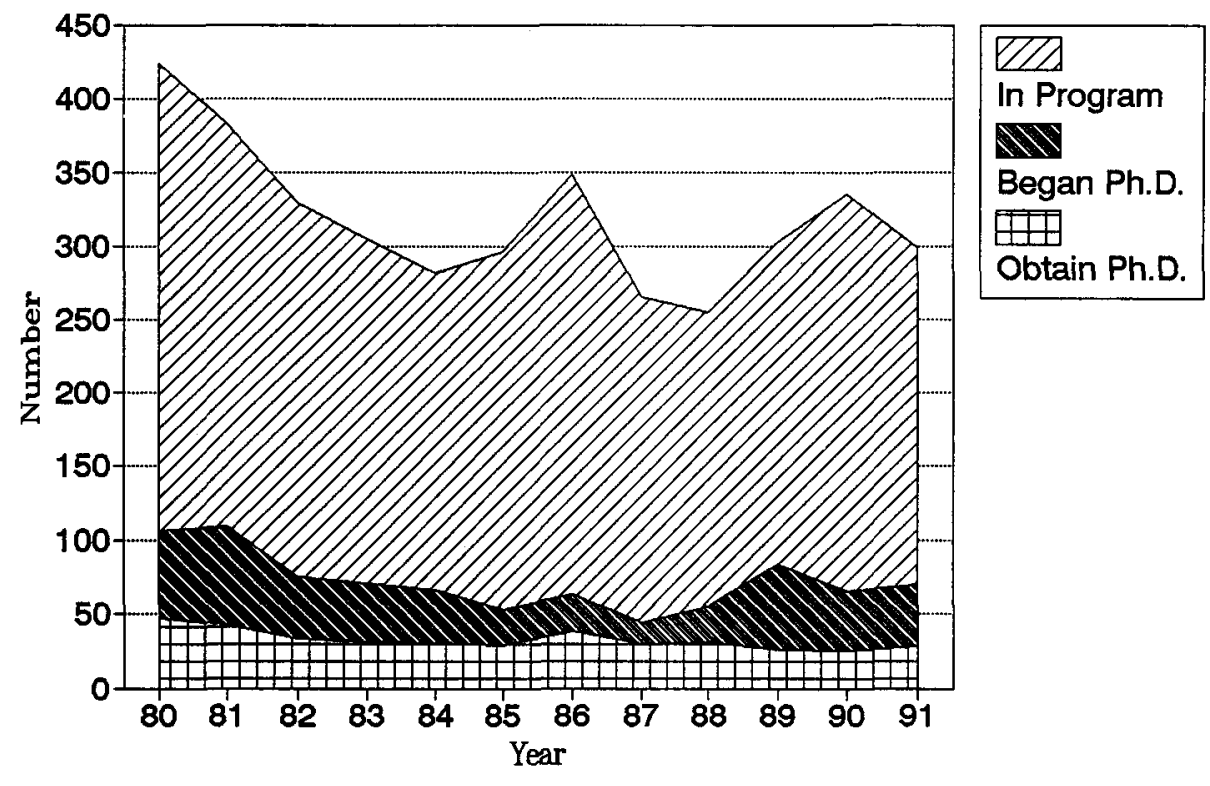

Source: APSA Survey of Departments, 1981-91.

African Americans in Ph.D. programs is that there is an increase in the number of African Americans obtaining Ph.D.s without a corresponding number beginning Ph.D. programs. This is, however, not the case. Between 1978 and 1980, 143 African Americans received Ph.D. degrees. ${ }^{1}$ Between 1989 and 1991, that number fell to a low of 86 . Dividing these numbers by three, one receives an annual rate of 47 students in 1980 and 28 students in 1991. Over the 11-year period the number of African Americans receiving Ph.D.s never reached its 1980 level.

For more than a decade academic institutions have been losing the battle of producing African-American Ph.D.s There have been declines in the number of students entering Ph.D. programs, in Ph.D. programs, and receiving Ph.D. degrees. Figure 2 shows that although in 1991 there was a decline in the number of all students obtaining Ph.D. degrees, there was an increase in the number of all students beginning Ph.D. programs and the number of all students currently enrolled in Ph.D. programs. This figure suggests that in general one should see more students obtaining $\mathrm{Ph} . \mathrm{D}$. degrees in political science in the future. There will be, however, a dearth of African Americans within that crop of future Ph.D.s.

\section{Top Producers of} African-American Ph.D.s

Several political science departments have been diligent in producing African-American Ph.D.s in the country. The 16 top producers of African-American Ph.D.s between 1934 and 1984 are shown in Table $1 .^{2}$

These institutions produced 217 African-American Ph.D.s between 1934 and 1984. Howard University and Clark-Atlanta, two predominantly African-American universities, received pivotal external funding from the Ford Foundation in the 1970s. Both of these universities were able to provide fellowships and expand faculty size. This enabled both institutions to recruit and to produce minority Ph.D.s in general, and African Americans in particular. Howard ranked as the top producer of African-American Ph.D.s between 1934 and 1984. Atlanta (or ClarkAtlanta) ranked fourth.

The 1986 Guide to Graduate Study in Political Science reports that 81 African Americans received doctorates in departments of political science since 1983 . The top producers for these years were Atlanta (15), 
FIGURE 2.

Total Students

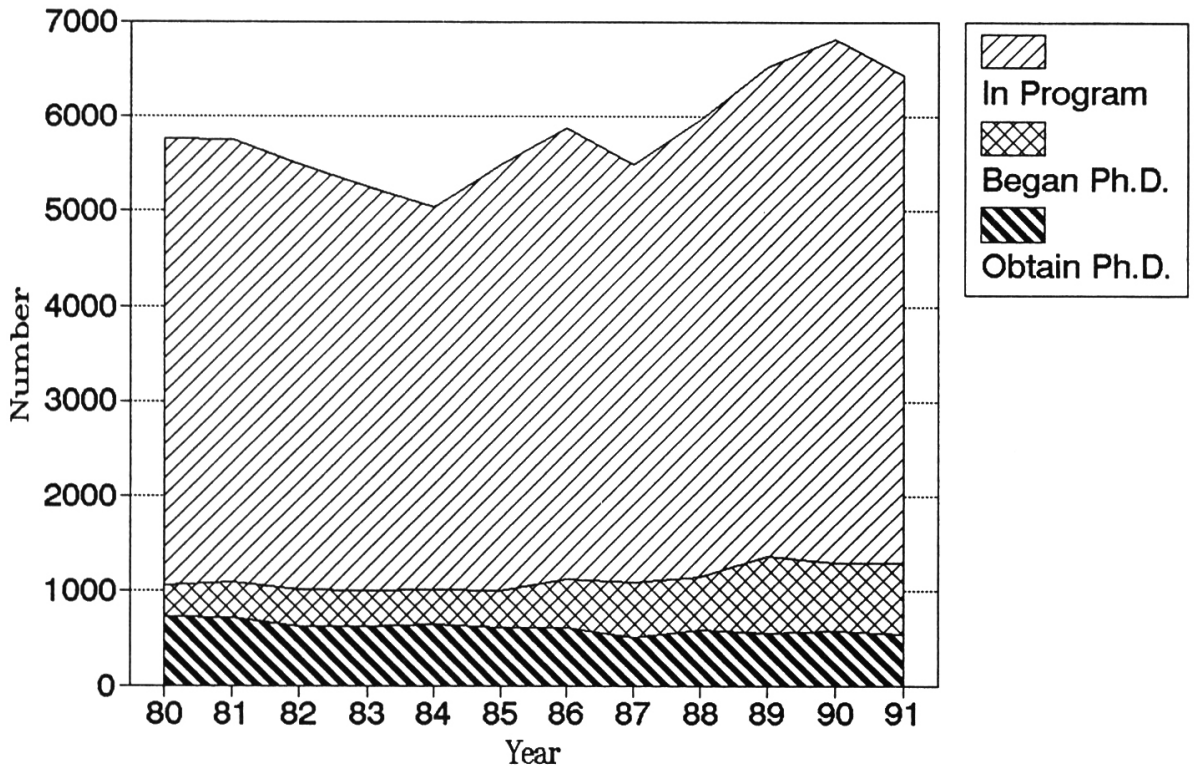

Source: Graduate Students and Faculty in Political Science Ph.D. and M.A. Programs, 1980-91, APSA.

Michigan (5), Howard (4), California at Berkeley (3), Chicago (3), and Ohio State (3). Two doctorates were awarded by Houston, Indiana, MIT, State University of New York at Binghampton, New York, Oklahoma, Pittsburgh, Temple, Washington State, Wayne State, and Yale.

Only 58 African Americans have graduated from departments of political science between 1987 and 1989 .

The 1989 Guide lists the top producers as the following: Clark-Atlanta (12), Boston University (4), Howard (3), New York (3), Yale (3), Cincinnati (2), Florida State (2), Georgia (2), Michigan (2), Temple (2), Tennessee (2), and Texas (2).

Cumulatively, the top producers of African American Ph.D.s have been the following departments: ClarkAtlanta (44), Howard (28), Michigan (23), Chicago (21), Claremont (20), Illinois (20), California at Berkeley (18), Ohio State (17), Harvard (16), Yale (15), Florida State (13), New York (13), Indiana (12), Wisconsin (12), Columbia (10), and Northwestern (10).

Between 1934 and 1983, aggregate data reveal that only 514 African Americans received political science doctorates. By 1989 , only an additional 100 African Americans have received political science Ph.D.s, bringing the total to 653. Again, it should be noted that these estimates probably overstate the number since many departments submit routinely the names of all graduates of color which may include black non-U.S.

\section{For more than a decade} academic institutions have been losing the battle of producing AfricanAmerican Ph.D.s. There have been declines in the number of AfricanAmerican students entering Ph.D. programs, in Ph.D. programs, and receiving Ph.D. degrees.

citizens. At any rate, the numbers are down and falling.

Only a small number of schools are producing the bulk of new African-American Ph.D.s. The top
TABLE 1.

Sixteen Top Producers of

African-American Ph.D.s

between 1934 and 1984

Howard

Claremont

Illinois

Chicago

Atlanta*

Michigan

U.C. Berkeley

Harvard

Ohio State

Florida State

Indiana

Wisconsin

Yale

Columbia

New York

Northwestern

*Atlanta was recently merged with Clark

College and the new name is Clark-Atlanta University.

Source: Maurice C. Woodard and Michael Preston, "African American Political Scientists: Where Are the New Ph.D.?" PS, Winter 1985 , p. 83.

producers of African-American Ph.D.s in political science between 1988 and 1990 are noted in Table 2.

The 1990 APSA survey notes a total of 66 African Americans receiving Ph.D. degrees over a three-year period. ${ }^{3}$ The six institutions in Table 2, out of $102 \mathrm{Ph}$.D.-granting institutions, produced $39 \%$ of all new African-American Ph.D.s.

The top producers in 1990 were not much different from the top producers in 1989. Four of the six top producers of African-American Ph.D.s in 1990 were also of the top seven producers in 1989 (see Table $3)$.

The 1989 APSA survey notes that

TABLE 2.

Top Producers of African-American Ph.D.s in Political Science in 1988,1989 , and 1990

\section{Clark-Atlanta}

Michigan

Wayne State

Delaware

North Carolina

Ohio State

Source: Graduate Students and Faculty in Political Science Ph.D. and M.A. Programs 1991, APSA, 1991. 
TABLE 3.

Top Producers of African-American Ph.D.s in Political Science

in 1987, 1988, and 1989

Clark-Atlanta

Michigan

Columbia

Howard

North Carolina

North Texas

Wayne State

Source: Graduate Students and Faculty in Political Science Ph.D. and M.A. Programs 1990, APSA, 1990.

a total of 68 African Americans received $\mathrm{Ph} . \mathrm{D}$. degrees over a threeyear period. These seven schools accounted for $43 \%$ of the total number of Ph.D.s granted to African Americans.

\section{Where African-American Students Are Enrolled}

Although the enrollment of African Americans is down, a number of departments have been diligent in recruiting them into their graduate programs. The departments with the largest number enrolled are listed in Table 4.

\section{TABLE 4.}

Top Departmental Enrollees of African Americans in Ph.D. Programs in 1991

Harvard

Michigan

Ohio State

Chicago

Howard

Yale

Clark-Atlanta

Maryland

SUNY-Binghampton

North Carolina

Temple

U.C. Berkeley

Northwestern

Wayne State

Emory

Illinois, Chicago

Mississippi

U.C., Santa Barbara

Claremont

Cornell

Missouri, St. Louis

UCLA

Source: Graduate Students and Faculty in Political Science Ph.D. and M.S. Programs, 1991 (Washington, DC: American Political Science Association, 1991), pp. 2-8.

\section{Linkages: Political Science, Public Administration, Public Policy, and International Affairs}

In the political science discipline, there are a number of subfields such as public administration, public policy, international affairs, political theory, parties and politics, comparative government, and international relations. Several of these subfields have risen to a status of having schools and departments of their own. The early linkages among these subfields are documented elsewhere (Waldo 1981, Stone and Stone 1976, and Somit and Tanenhaus 1967). Many of these schools offer doctoral degrees and may provide alternative routes for African Americans to

\section{Only a small number of} schools are producing the bulk of new African-

\section{American Ph.D.s.}

obtain political science training in nontraditional or nondepartmental political science settings.

The number of African Americans who have received Ph.D.s through these other avenues is unknown. Investigation of these other avenues will allow researchers to examine the current pipeline of students pursuing Ph.D. degrees and the number of African-American faculty within these nontraditional political science departments.

Inclusion of these other areas in an investigation of African Americans in Ph.D. programs increases the number of students pursuing the Ph.D. degree by 133 students. The majority of these 133 students are in departments of public administration (85 students). ${ }^{4}$ Thirty-five students are in six schools of public affairs. ${ }^{5}$ And, thirteen students are in four schools of international relations. ${ }^{6}$ These schools with African-American Ph.D. students are listed in Tables 5, 6 , and 7.

These schools are considered viable avenues through which African-

American students are pursuing political science training in areas of specialization.

In 1989, 303 African-American students were pursuing Ph.D.s in political science through traditional political science departments. In that same year, 133 African-American students were pursuing $\mathrm{Ph} . \mathrm{D}$. degrees in public administration programs,

\section{TABLE 5.}

Public Administration Programs with African-American Ph.D. Students, 1989

St. Louis University
SUNY, Albany
Wayne State
Alabama
Delaware
Florida International
Temple
SUNY, Binghampton
Texas, Arlington
George Mason
Virginia Commonwealth
Virginia
American
Florida Atlantic
Florida State
University of Georgia
University of Mississippi
Kent State
Pittsburgh
Arizona State
Cleveland State
Oklahoma
Texas, Dallas

Source: NASPAA 1989 survey.

TABLE 6.

Schools of Public Affairs*

Brandeis

Carnegie-Mellon

University of Colorado, Denver

North Carolina

Southern California

SUNY, Albany

*Schools responding to the NASPAA survey and members of APPAM.

Source: Graduate Students and Faculty in Political Science Ph.D. and M.A. Programs 1990, APSA, 1990.

\section{TABLE 7.}

Schools of International Relations

American University

Denver University

SAIS, Johns Hopkins

University of Southern California

Source: Graduate Students and Faculty in Political Science Ph.D. and M.A. Programs 1990, APSA, 1990. 
FIGURE 3.

\section{African-American Proportion of Faculty}

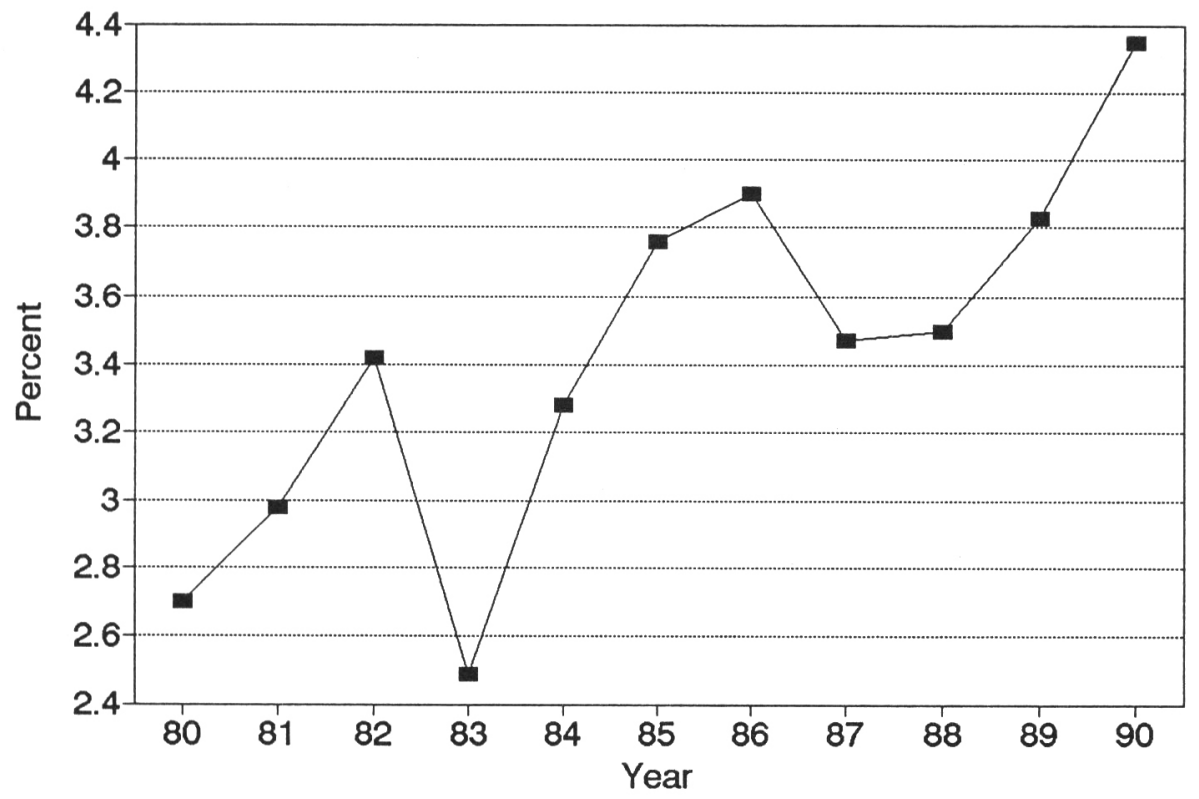

Source: Survey of Departments, APSA, 1980-91.

FIGURE 4.

Non-African-American Faculty, 1980

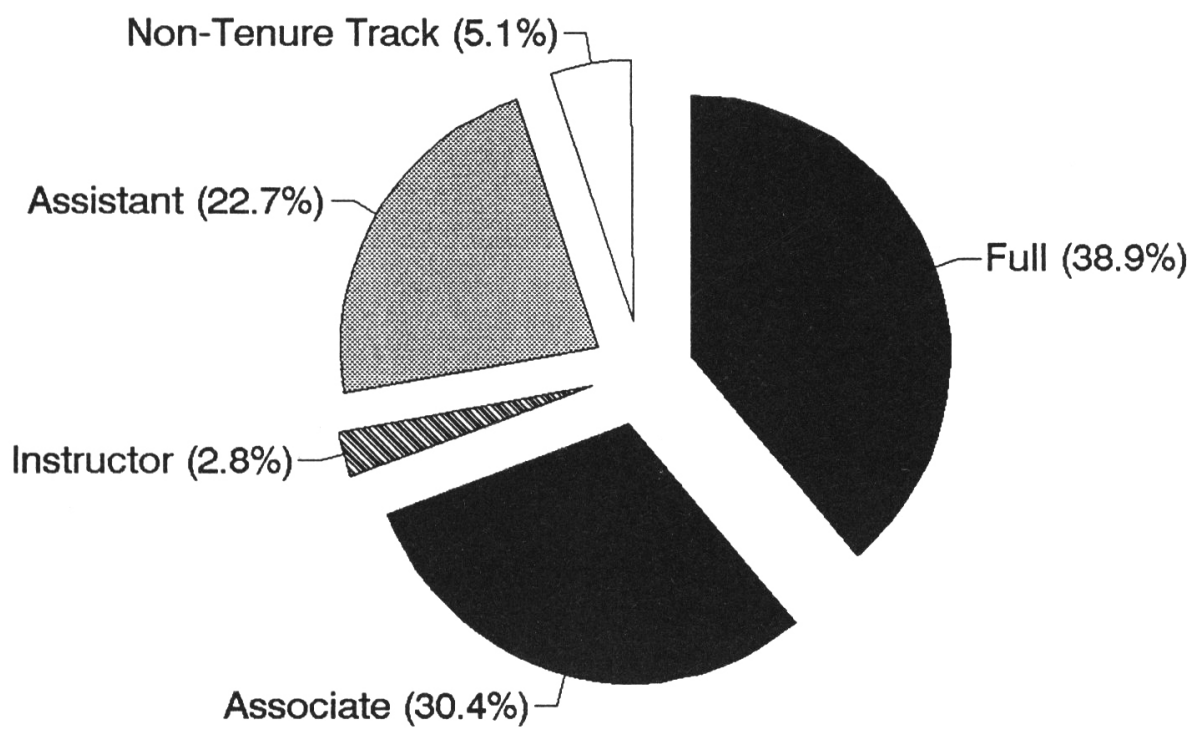

Source: Survey of Departments, APSA, 1980. public affairs schools, and schools of international relations. Some public administration programs are offered in departments of political science. Still others are located in schools of public administration.

\section{Faculty}

In 1980, African Americans constituted $2.7 \%$ of the full-time faculty within political science departments. This rate increased to $4.35 \%$ in 1990 , representing a $61 \%$ increase over the 10 -year period. Although this increase suggests positive improvements are being made, less than five percent of all faculty within political science departments are African-American.? The 1990 rate marks the largest percentage of this faculty over the 10-year period. The lowest percentage was in 1983, when it only reached $2.5 \%$ (Figure 3 ). For the 11 -year period, the average proportion is $3.4 \%$.

Another indicator of AfricanAmerican faculty progress is academic rank. Two snapshots of faculty rank were taken. The percent of non-African-American faculty and African-American faculty by academic rank for 1980 and 1990 were compared (Figures 4-7). As these figures show, tremendous disparities exist by race of faculty, within year and between years. In 1980, of nonAfrican-American, full-time faculty members, $39 \%$ were full professors, $30 \%$ were associate professors, $23 \%$ were assistant professors, $3 \%$ were instructors, and $5 \%$ were nontenured track professors (Figure 4). For African Americans, $21 \%$ were full professors, $20 \%$ were associate professors, $34 \%$ were assistant professors, $15 \%$ were instructors, and $10 \%$ were in nontenured track positions (Figure 5).

By 1990, of non-African-American faculty, $43 \%$ were full professors, $25 \%$ were associate professors, $21 \%$ were assistant professors, $2 \%$ were instructors, and $8 \%$ were nontenured track professors (Figure 6). Twenty percent of African Americans were full professors, $24 \%$ were associate professors, $38 \%$ were assistant professors, $5 \%$ were instructors, and 
FIGURE 5.

African-American Faculty, 1980

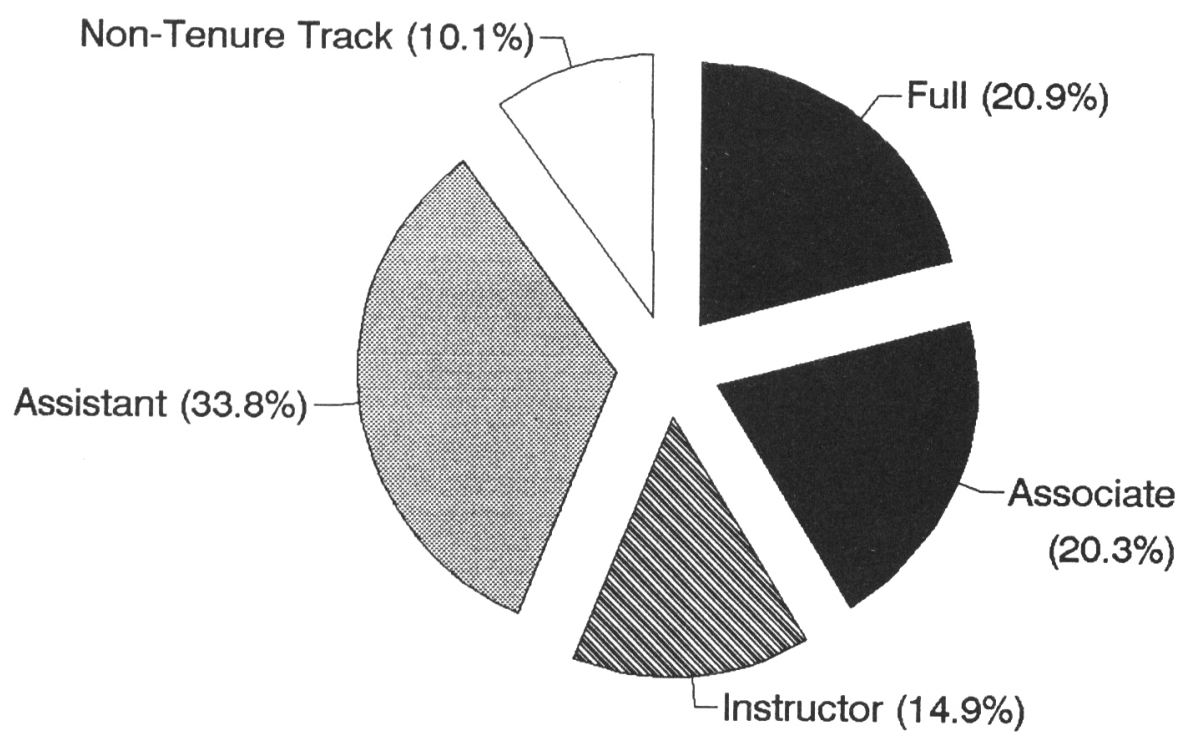

Source: Survey of Departments, APSA, 1980.

FIGURE 6.

Non-African-American Faculty, 1990

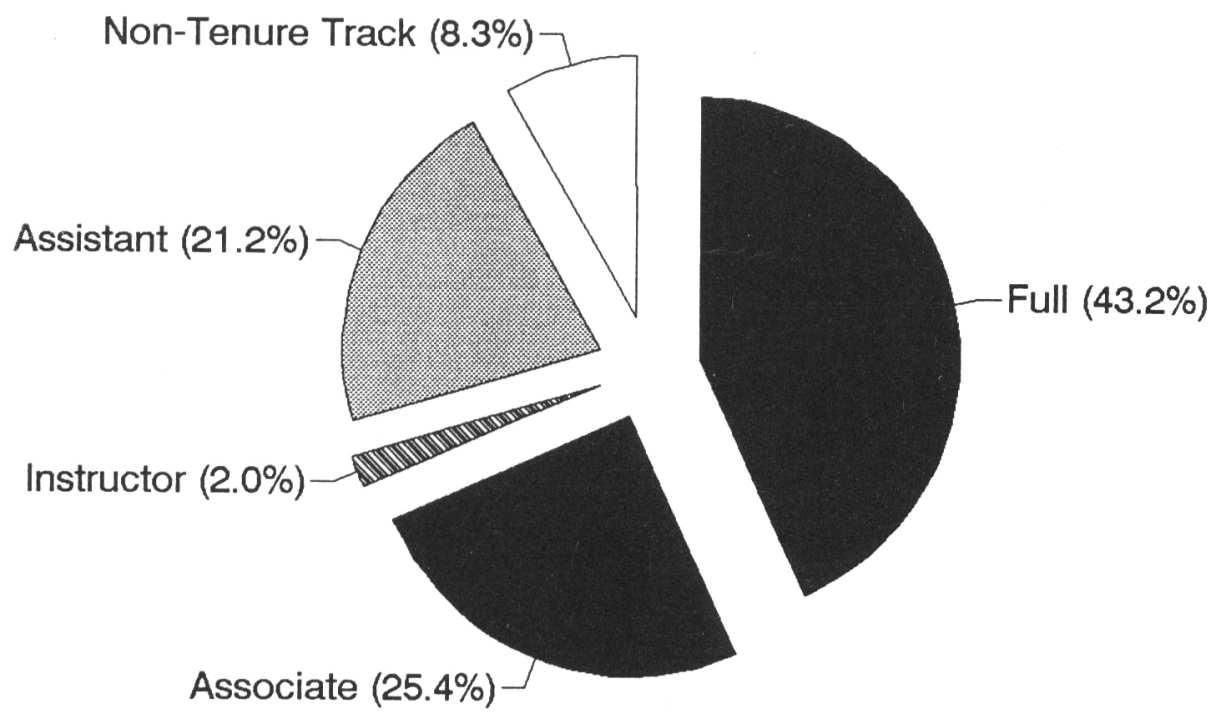

Source: Survey of Departments, APSA, 1991.
$14 \%$ were listed as nontenured track faculty (Figure 7).

Figures 4 and 6 show that nonAfrican-American faculty increased their presence among full professorships between 1980 and 1990 from $39 \%$ to $43 \%$. For African-American faculty, the percentage of full professors remained virtually unchanged (Figures 5 and 7). In addition, the share of tenured positions, usually denoted as associate and full professorships, remained virtually unchanged over the 10-year period for both groups. For non-AfricanAmerican faculty in 1980 , the combined percentage of associate and full professorships was $69 \%$. For African-American faculty, the combined rate was $41 \%$. In 1990 , the combined rates for non-AfricanAmerican faculty and AfricanAmerican faculty were $67 \%$ and $44 \%$, respectively.

\section{Conclusions}

Over the past decade African Americans have made little progress in becoming entrenched in the political science profession. The purpose of this paper is to assess the status of African Americans within the political science profession. Our findings suggest that over a ten-year period:

(1) the number of African-American students entering political science departments has declined; (2) the number of African Americans receiving Ph.D.s in political science has declined; (3) the number of AfricanAmerican students pursuing Ph.D. degrees has declined; (4) the proportion of political science faculty that is African-American has remained less than five percent; and (5) the proportionate rank of tenured AfricanAmerican faculty has remained unchanged.

The American Political Science Association has taken an aggressive and positive role in attempting to alleviate these ostensible problems. The Association authorized the establishment of the African American Fellowship Program in 1969, in response to the recommendation by the APSA Committee on the Status of Blacks in the Profession. In 1984, the APSA Committee on the Status of Blacks held a conference of selected political scientists to discuss 
FIGURE 7.

African-American Faculty, 1990

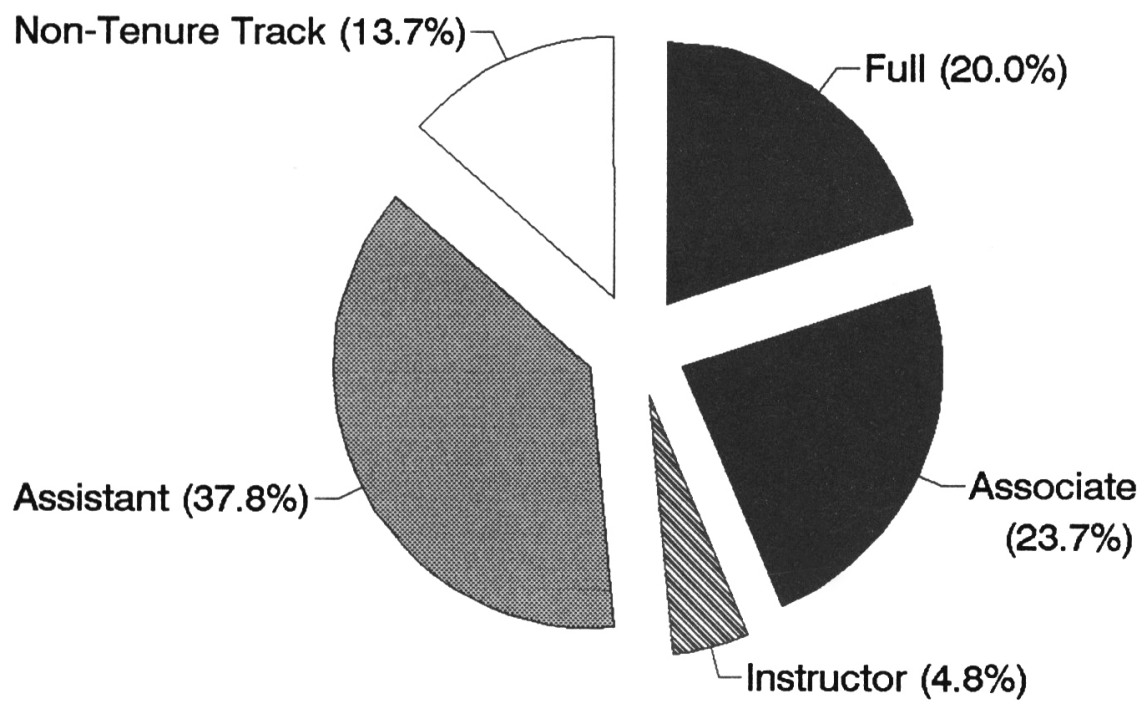

Source: Survey of Departments, APSA, 1991.

what the Association could do to increase the supply of black political scientists (Preston and Woodard 1984). Some of the leading producers of African-American Ph.D.s have recruited heavily from this program. In addition, the APSA established the Ralph Bunche Summer Institute in 1986 to "encourage African American students to pursue academic careers in political science." The objectives of the summer institute are:

To enhance the writing, research and analytical skills of the participants, making them more competitive applicants for graduate school admission and financial assistance.

To improve students' use of computers for statistical analysis of research data used in the study of political science.

To expose the participants to leading issues and problems in the discipline and profession of political science.

To introduce participants to leading scholars in the discipline.

To inform students of career opportunities for political scientists.

(APSA Ralph Bunche Brochure, 1992)

As the data show, however, the efforts of the APSA alone will not correct the decline in the future supply of African Americans in the political science profession. Many of the top producers of Ph.D.s in political science have stopped recruiting African-American students. Ideally, these earlier producers will make a serious effort once again to seek to diversify their student population. In addition, other departments of political science around the nation must take an active role in reversing the ebbing tide.

\section{Notes}

We would like to thank Alma Beals of NASPAA and Michael Brintnall of the APSA for providing data for this research.

1. The APSA annual survey asked departments of political science how many black $\mathrm{Ph}$.D. recipients they had over the last three years not how many recipients in the last year. Thus, we divide the numbers presented in the APSA report by three.

2. Ralph Bunche, former APSA President and Nobel Laureate, was the first African American to receive the Ph.D. in political science. He graduated from Harvard University in 1934. Jewel Prestage, Prairie View A\&M University, was the first AfricanAmerican woman to receive the doctorate. She graduated from the University of Iowa in 1954.

3. After adjusting for missing data, the APSA estimates that 86 African Americans received $P h . D$. degrees in 1989.

4. These are public administration departments which responded to the National Association of Schools of Public Affairs and Administration (NASPAA) 1989 survey. 5. These are 1988 Association for Public Policy Analysis and Management (APPAM) member schools that responded to either the NASPAA survey or the APSA survey of departments.

6. These schools responded to the APSA 1989 survey.

7. In 1987, the APSA changed its survey instrument from black to African-American. Thus the $2.7 \%$ calculated in 1980 may include non-African-American faculty. This probably shows up in the number of students in graduate schools and in the production of Ph.D.s as alluded to earlier.

\section{References}

APSA Departmental Services Program, 1980-81 Survey of Departments, APSA, 1981.

APSA Departmental Services Program, 1981-82 Survey of Departments, APSA, 1982.

AP SA Departmental Services Program, 1982-83 Survey of Departments, APSA, 1983.

APSA Departmental Services Program, 1983-84 Survey of Departments, APSA, 1984.

APSA Departmental Services Program, 1984-85 Survey of Departments, APSA, 1985.

APSA Departmental Services Program, 1985-86 Survey of Departments, APSA, 1986.

APSA Departmental Services Program, 1986-87 Survey of Departments, APSA, 1987.

APSA Departmental Services Program, 1987-88 Survey of Departments, APSA, 1988.

APSA Departmental Services Program, 1988-89 Survey of Departments, APSA 1989.

APSA Departmental Services Program, 1989-90 Survey of Departments, APSA, 1990.

APSA Departmental Services Program, 1990-91 Survey of Departments, APSA, 1991.

Association for Public Policy Analysis and Management 1988 Membership Directory, APPAM.

Chronicle of Higher Education. 1990. "Universities Awarded Record Number of Doctorates Last Year; Foreign Students Thought to Account for Much of the Increase," April 25, Vol. XXXVI, No. 32, p. 1.

Graduate Students and Faculty in Political Science Ph.D. and M.A. Programs 1980, APSA, 1980, p. 1.

Graduate Students and Faculty in Political Science Ph.D. and M.A. Programs 1981, APSA, 1981, p. 1.

Graduate Students and Faculty in Political Science Ph.D. and M.A. Programs 1982, APSA, 1982, p. 1.

Graduate Students and Faculty in Political Science Ph.D. and M.A. Programs 1983, APSA, 1983, p. 1.

Graduate Students and Faculty in Political Science Ph.D. and M.A. Programs 1984, APSA, 1984, p. 1.

Graduate Students and Faculty in Political 
Science Ph.D. and M.A. Programs 1985, APSA, 1985, p. 1.

Graduate Students and Faculty in Political Science Ph.D. and M.A. Programs 1986, APSA, 1986, p. 1.

Graduate Students and Faculty in Political Science Ph.D. and M.A. Programs 1987, APSA, 1987, p. 1.

Graduate Students and Faculty in Political Science Ph.D. and M.A. Programs 1988, APSA, 1988, p. 1.

Graduate Students and Faculty in Political Science Ph.D. and M.A. Programs 1989, APSA, 1989, p. 1.

Graduate Students and Faculty in Political Science Ph.D. and M.A. Programs 1990, APSA, 1990, p. 1.

Graduate Students and Faculty in Political Science Ph.D. and M.A. Programs 1991, APSA, 1991, p. 1.

Highlights From the 1990 Survey of Earned Doctorates, National Research Council. Office of Scientific and Engineering Per- sonnel, 2101 Constitution Ave., N.W., Washington, DC 20418.

Preston, Michael and Maurice Woodard. 1984. "The Rise and Decline of Black Political Scientists in the Profession," PS, Fall, pp. 787-92.

Preston, Michael and Maurice Woodard. 1990. "Blacks in Public Administration: An Endangered Species," in Public Administration: The State of the Discipline, edited by Naomi Lynn and Aaron Wildavsky, Chatham House Publishers, Inc.

Programs in Public Affairs and Administration, 1988 Directory, NASPAA, 1988.

Ralph Bunche Summer Institute Brochure, APSA, 1992.

Somit, Albert and Joseph Tanenhaus. 1967. The Development of American Political Science. Boston: Allyn and Bacon.

Stone, Alice B. and Donald Stone. 1976. "Early Development of Education," in Public Administration: Past, Present, Future, edited by Frederick C. Mosher.
Survey of Public Affairs and Administration Programs: Academic Year 1988-1989, NASPAA, 1989.

Waldo, Dwight. 1981. The Enterprise of Public Administration. New York: Chandler and Sharp.

Woodard, Maurice and Michael Preston. 1985. "Black Political Scientists: Where Are the New Ph.D.s?' PS, Winter, pp. 80-88.

\section{About the Authors}

Sheila Ards is an assistant professor in the School of Public Affairs, University of Maryland, College Park. She teaches courses in social policy and quantitative methods.

Maurice C. Woodard is a staff associate at the American Political Science Association and professor and director of the graduate program in the department of political science, Howard University.

\title{
NSF Funding Opportunities for Political Science Research
}

\author{
Frank P. Scioli, Jr., The National Science Foundation \\ James E. Campbell, The National Science Foundation
}

First, this report is to update political scientists on the extent and range of current opportunities for research funding by the National Science Foundation. To the point, things are looking good. Relatedly, we want to encourage submitting carefully constructed proposals for theoretically important and empirically rigorous research. (Read: So no half-baked, trivial, story-telling proposals. Just your best stuff.)

There are two reasons to feel optimistic about funding for political science research and to encourage political scientists to seek NSF support for their research. The first reason for optimism is that the Political Science Program at NSF has done quite well over the last few years. Nowhere is this better reflected than in the program's budget. The budget for the Political Science Program has grown and is continuing to grow. In fiscal year 1985, the program's budget was $\$ 3.3$ million. In fiscal year 1992, the current fiscal year, the budget is about $\$ 4.2$ million. In the coming fiscal year, the budget for the program is expected to increase again. The Political Science Program's effective budget, if Congress concurs with the president's budget request, will be something over $\$ 5$ million. While not all of these funds are available for new projects (we do have some longterm commitments) about $\mathbf{7 5 \%}$ are.

The long-range prospects for the program are as bright as the immediate budget picture. With the reorganization within NSF establishing a directorate of Social,

In terms of the budget and in terms of organizationalrestructuring, political science is doing well in the Foundation.

Behavioral and Economic Sciences (disentangling the social sciences from the same directorate that housed biology) and with the reestablishment of the Political Science "rotator" or Associate Program Director's position, we should be even better able to serve the research needs of the discipline.

In terms of the budget and in terms of organizational restructuring, political science is doing well in the Foundation. One important reason" for this success, other than the wisdom of the program's leadership, is the quality of the proposals that we have received. Programs are rewarded for attracting theoretically interesting and methodologically sound proposals. We hope that the recent budget growth and organizational developments encourage more such proposals in the future.

A second reason for optimism is that there are opportunities for funding at NSF that political scientists have yet to exploit fully. Beyond the general call for grant proposals by the Political Science Program, there is a wide variety of specialized programs and initiatives at NSF that seem to be underutilized by political scientists, perhaps because they are not aware of or may need to be reminded of the existence of these opportunities. These programs and initiatives fall into several groups:

(1) Other programs in the Social and Economic Science Division (the Division that houses the Political Science Program). There are six other programs in this division. The largest, as you might guess, is the 